\title{
Transactions
}

Cite this: Dalton Trans., 2012, 41, 9601

www.rsc.org/dalton

COMMUNICATION

\section{An access to base-stabilized three-membered silicon heterocycles $\uparrow$}

\author{
Ramachandran Azhakar, Herbert W. Roesky,* Rajendra S. Ghadwal,* Julian J. Holstein and Birger Dittrich* \\ Received 13th June 2012, Accepted 28th June 2012 \\ DOI: 10.1039/c2dt31326j
}

The three-membered silacyclic ring compounds $\mathrm{LSi}\left[\mathrm{N}_{2}(\mathrm{Ph})_{2}\right]-$ $t \mathrm{Bu}(1), \mathrm{LSi}\left[\mathrm{HCN}(\mathrm{Ph})_{2}\right] t \mathrm{Bu}(2)$ and $\mathrm{LSi}\left[\mathrm{C}_{2}(\mathrm{Ph})_{2}\right] t \mathrm{Bu}(3)$ were obtained by the treatment of base stabilized monoalkylsilylenes LSitBu $\left(\mathrm{L}=\mathrm{PhC}(\mathrm{N} t \mathrm{Bu})_{2}\right)$ with $\mathrm{PhN}=\mathrm{NPh}$, $\mathrm{PhN}=\mathrm{CHPh}$ and $\mathrm{PhC} \equiv \mathrm{CPh}$. The reaction of $\mathrm{PhN}=\mathrm{NPh}$ and $\mathrm{PhC} \equiv \mathrm{CPh}$ with $\mathrm{LSi}$ Bu shows a different reactivity pattern with base stabilized monochlorosilylene LSiCl. The arrangement of the three-membered ring ( $\mathrm{SiNN}$ ) in 1 is the first structurally isolated example of a siladiaziridine compound.

Three-membered ring compounds possessing higher coordinate group 14 elements especially silicon at the position adjacent to the heteroatom have received considerable attention because of their unique structures and also their wide application in synthetic chemistry. ${ }^{1}$ These three-membered ring compounds bearing a silicon atom are interesting for chemists, due to their high strain and novel bonding arrangement within the ring. ${ }^{2}$ Moreover, these systems can be compared with epoxides and aziridines which have become an important class of compounds. ${ }^{3,4}$ Epoxides as well as aziridines are natural products and show a great number of transformations. ${ }^{4}$ Related reactions are expected with silicon containing three-membered rings. In the case of Brook rearrangement, the transition state has been proposed as a three-membered ring compound bearing a pentacoordinate silicon at the position adjacent to an oxygen. ${ }^{5}$ Further Nevárez and Woerpel reported on the dearomatization reaction which involves treatment of benzaldehyde with silaziridine with an aryl group either on carbon or nitrogen atoms, which is considered to be driven by the relief of the ring strain of the threemembered ring. ${ }^{6}$ Recently there has been emerging interest in the replacement of carbon atoms with silicons for developing new innovative drugs. ${ }^{7}$ Several bioactive silacycles have been reported. One example is sila-haloperidol which shows a different metabolism pattern when compared to that of the carbon analogue. ${ }^{8}$ However, due to the high ring strain of the threemembered ring system only a few silicon compounds with heteroatoms have been reported so far. ${ }^{9}$

Institut für Anorganische Chemie, Universität Göttingen,

Tammannstrasse 4, 37077 Göttingen, Germany.

E-mail:hroesky@gwdg.de,rghadwal@uni-goettingen.de, bdittri@gwdg.de

$\dagger$ Electronic supplementary information (ESI) available: Experimental section. CCDC 883101, 883102, 883103 for $\mathbf{1}, \mathbf{2}$ and $\mathbf{3}$ respectively. For ESI and crystallographic data in CIF or other electronic format see DOI: $10.1039 / \mathrm{c} 2 \mathrm{dt} 31326 \mathrm{j}$
Compounds with silicon(IV) atoms are quite easy to access from $\mathrm{Si}$ (II) by the oxidative addition reaction. ${ }^{9 a-\mathrm{e}}$ The divalent silicon species called silylenes were generated as short-lived intermediates in numerous thermal and photochemical reactions from organosilicon precursors. ${ }^{10}$ The existence of silylenes has been evidenced by chemical trapping and spectroscopic methods in the fluid phase or in low-temperature matrices. Initially the stable silylenes were isolated as $N$-heterocyclic silylene (NHSi) by West et al. in 1994. ${ }^{11}$ One can compare the reactivities of NHSis with those of the $\mathrm{N}$-heterocyclic carbenes (NHCs). The latter find already a number of applications. ${ }^{12-14}$ In 2006, we reported the three coordinate stable chlorosilylene $\mathrm{LSiCl}$ $\left(\mathrm{L}=\mathrm{PhC}(\mathrm{N} t \mathrm{Bu})_{2}\right)$ stabilized by an amidinato ligand in less than $10 \%$ yield using potassium as a reducing agent. ${ }^{15}$ Subsequently we reported the synthesis of $\mathrm{LSiCl}$ utilizing $\mathrm{LiN}\left(\mathrm{SiMe}_{3}\right)_{2}$ as a reducing agent to get higher yields without using hazardous reducing agents. ${ }^{16}$ Currently we are interested in the chemistry of silylenes and utilized them as $\sigma$-donor ligands for transition metal complexes, ${ }^{17}$ oxidative addition reactions with organic substrates ${ }^{18}$ and Lewis bases. ${ }^{19}$ Recently we synthesized the monoalkylsilylene $\mathrm{LSi} t \mathrm{Bu}$ by a facile metathesis reaction treating LSiCl with $\mathrm{Li} t \mathrm{Bu}^{20}$ We observed a quite different reactivity pattern of $\mathrm{LSi} t \mathrm{Bu}$ with $\mathrm{N}_{2} \mathrm{O}$ when compared with that of $\mathrm{LSiCl}$. In the case of $\mathrm{LSi} t \mathrm{Bu}$ we obtained $[\mathrm{LSi} t \mathrm{Bu}(\mu-\mathrm{O})]_{2}$ containing a four-membered $\mathrm{Si}_{2} \mathrm{O}_{2}$ ring. ${ }^{20}$ In contrast the reaction of $\mathrm{LSiCl}$ proceeds to the trimer $[\mathrm{LSi}(\mu-\mathrm{O}) \mathrm{Cl}]_{3}$ with a $\mathrm{Si}_{3} \mathrm{O}_{3}$ six-membered ring. ${ }^{19 b}$ We presume that the difference in reactivity is due to the presence of the bulky $t \mathrm{Bu}$ substituent attached to the silicon atom. This motivated us to explore the chemistry of LSitBu further and to compare its reactivity pattern with $\mathrm{LSiCl}$. We treated $\mathrm{LSi} t \mathrm{Bu}$ with $\mathrm{PhN}=\mathrm{NPh}, \mathrm{PhN}=\mathrm{CHPh}$ and $\mathrm{PhC} \equiv \mathrm{CPh}$ leading to the products $\mathrm{LSi}\left[\mathrm{N}_{2}(\mathrm{Ph})_{2}\right] t \mathrm{Bu}(\mathbf{1}), \mathrm{LSi}\left[\mathrm{HCN}(\mathrm{Ph})_{2}\right] t \mathrm{Bu}$ (2) and $\mathrm{LSi}\left[\mathrm{C}_{2}(\mathrm{Ph})_{2}\right] t \mathrm{Bu}(3)$. These three reactions yielded the three-membered silacyclic ring compounds. The reaction of $\mathrm{PhN}=\mathrm{NPh}$ and $\mathrm{PhC} \equiv \mathrm{CPh}$ with $\mathrm{LSi}$ Bu shows a different reactivity pattern when compared with that of LSiCl. The reaction of $\mathrm{LSiCl}$ with $\mathrm{PhN}=\mathrm{NPh}$ resulted in the formation of the fused two five-membered unsymmetric rings formed by $\mathrm{C}-\mathrm{H}$ bond activation and $\mathrm{LSiHCl}_{2}$ elimination. ${ }^{21}$ The reaction of $\mathrm{LSiCl}$ with $\mathrm{PhC} \equiv \mathrm{CPh}$ proceeds in a $2: 1$ ratio to yield the fourmembered ring compound ${ }^{16}$ while LSitBu yielded the silacyclopropene 3. It is of interest to mention that silylenes react with alkynes to form a variety of small membered silacycles. ${ }^{9,22}$ The formation of the SiNN three-membered ring in $\mathbf{1}$ is the first structurally isolated example of a siladiaziridine compound.

Compounds 1, 2 and $\mathbf{3}$ were obtained in good yields when $\mathrm{LSi} t \mathrm{Bu}$ was treated with $\mathrm{PhN}=\mathrm{NPh}, \mathrm{PhN}=\mathrm{CHPh}$ and 

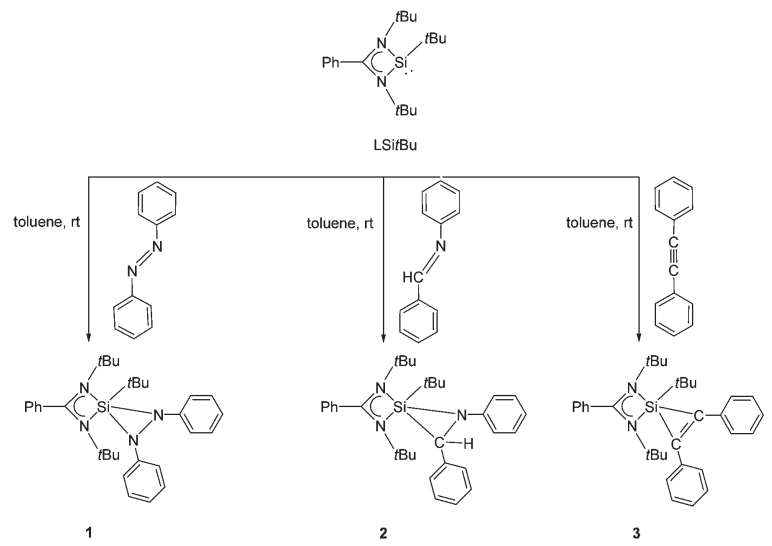

Scheme 1 Synthesis of 1-3.

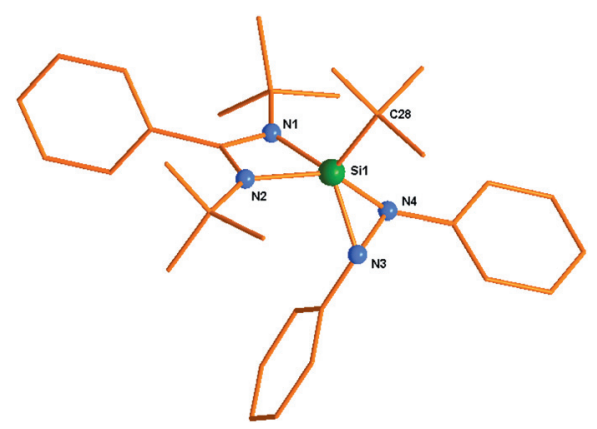

Fig. 1 Molecular structure of $\mathbf{1}$. Selected bond lengths $[\AA]$ and angles []: Si1-N1 1.8207(14), Si1-N2 1.9368(15), Si1-N3 1.7466(15), Si1N4 1.7938(15), Si1-C28 1.8933(17), N3-N4 1.5240(18); N1-Si1-N2 69.83(6), N3-Si1-N4 50.97(6), N2-Si1-C28 104.83(7), N1-Si1-N3 127.20(7), N2-Si1-N4 144.22(7), N2-Si1-C28 104.83(7), N3-Si1-C28 117.72(7), Si1-N3-N4 66.12(8), N3-N4-Si1 62.91(8).

$\mathrm{PhC} \equiv \mathrm{CPh}$ in a $1: 1$ ratio as shown in Scheme 1. Compounds 1-3 are soluble in common organic solvents. They are stable both in the solid state as well as in solution without any decomposition under an inert gas atmosphere. The molecular structures of 1-3 were unequivocally established by single crystal X-ray structural analyses. Furthermore they were fully characterized by NMR spectroscopy, EI-MS and elemental analysis.

The ${ }^{29} \mathrm{Si}$ NMR spectrum of $\mathbf{1}$ shows a single resonance at $\delta-99.6 \mathrm{ppm}$, which is upfield shifted when compared with that of $\mathrm{LSi} t \mathrm{Bu}(\delta 61.5 \mathrm{ppm}){ }^{20}$ The $t \mathrm{Bu}$ protons of compound $\mathbf{1}$ in the ${ }^{1} \mathrm{H}$ NMR spectrum exhibit a double resonance of equal intensity for the $t \mathrm{Bu}$ groups that reside on nitrogen atoms $(\delta 0.98$ and $1.23 \mathrm{ppm})$. The $t \mathrm{Bu}$ protons attached to the silicon atom resonate at $1.31 \mathrm{ppm}$. In addition 1 shows its molecular ion in the mass spectrum at $\mathrm{m} / \mathrm{z} 498$.

The siladiaziridine product $\mathbf{1}$ crystallizes in the triclinic space group $P \overline{1}$ and the molecular structure is shown in Fig. 1. We propose that the reaction of $\mathrm{LSi} t \mathrm{Bu}$ with $\mathrm{PhN}=\mathrm{NPh}$ followed the $[1+2]$-cycloaddition reaction. The silicon atom is five coordinate and the coordination environment is made up from four nitrogen atoms and a carbon atom. The structural index $\tau$ which defines the extent of deviation from trigonal bipyramidal to square pyramidal geometry $(\tau=1$ for perfect trigonal

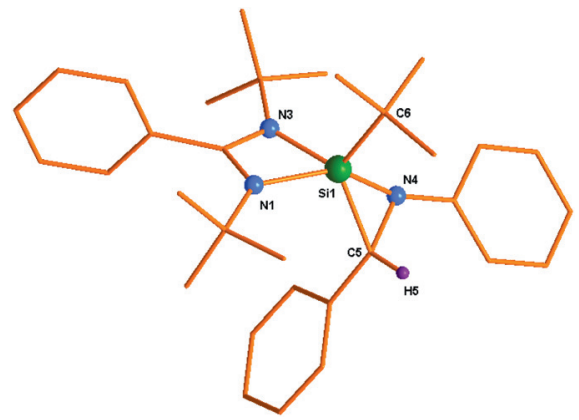

Fig. 2 Molecular structure of 2. Selected bond lengths $[\AA]$ and angles [ ${ }^{\circ}$ : Si1-N1 1.9718(11), Si1-N3 1.8226(10), Si1-N4 1.7795(11), Si1N1 1.9718(11), Si1-C6 1.9160(13), Si1-C5 1.8622(13), C5-N4 1.4878(15); N1-Si1-N3 68.97(5), N3-Si1-C5 124.85(5), N1-Si1-C6 102.45(6), N1-Si1-N4 148.28(5), N4-Si1-C5 48.16(5), C5-Si1-C6 120.80(6), N3-Si1-C5 124.85(5), Si1-N4-C5 68.83(7), N4-C5-Si1 63.01(6).

bipyramidal; $\tau=0$ for perfect square based pyramidal ${ }^{23}$ ) is 0.28 , indicating strong deviation from the regular trigonal bipyramidal geometry and closer to square pyramidal geometry. The N1-Si1-N2 bite angle between the silicon atom with the backbone ligand is $69.83(6)^{\circ}$. The distance between the $\mathrm{Si}$ and the $t \mathrm{Bu}$ carbon atom is $1.8933(17) \AA$. The angles of the newly formed NSiN three-membered ring are N3-Si1-N4 $\left(50.97(6)^{\circ}\right)$, Si1-N3-N4 $\left(66.12(8)^{\circ}\right)$ and N3-N4-Sil $\left(62.91(8)^{\circ}\right)$. The bond distances within the ring are Si1-N3 (1.7466(15) $\AA$ ), N3-N4

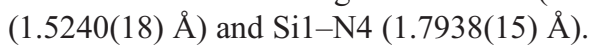

The silaaziridine 2 exhibits a single resonance at $\delta-104.6 \mathrm{ppm}$ in its ${ }^{29} \mathrm{Si}$ NMR spectrum. Similar to compound $\mathbf{1}$, the $t \mathrm{Bu}$ protons attached to the nitrogen atoms of compound $\mathbf{2}$ show a double resonance of equal intensity in the ${ }^{1} \mathrm{H}$ NMR spectrum $(\delta 0.76,1.24 \mathrm{ppm})$. The $t \mathrm{Bu}$ protons that reside at the silicon atom resonate at $1.35 \mathrm{ppm}$. The imino proton resonates at $\delta 3.81 \mathrm{ppm}$. Further compound $\mathbf{2}$ displays its molecular ion in the mass spectrum at $m / z 497$.

The molecular structure of compound $\mathbf{2}$ is shown in Fig. 2. It crystallizes in the triclinic space group $P \overline{1}$. The silicon atom is five coordinate comprising three nitrogen atoms and two carbon atoms and displays a distorted square pyramidal geometry with $\tau=0.39$. The N1-Si-N3 bite angle is $68.97(5)^{\circ}$. The angles of the newly formed NSiC three-membered ring are N4-Si-C5 $\left(48.16(5)^{\circ}\right)$, Si1-N4-C5 $\left(68.83(7)^{\circ}\right)$ and N4-C5-Si1 $\left(63.01(6)^{\circ}\right)$. Correspondingly the bond distances within the ring are Sil-N4

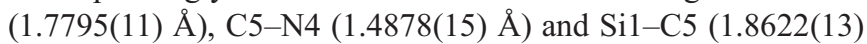
$\AA)$. These values are quite comparable to those of $\mathrm{Si}-\mathrm{N},{ }^{24}$ $\mathrm{C}-\mathrm{N}^{24 b}$ and $\mathrm{Si}-\mathrm{C}^{24 b}$ distances reported in the literature.

The ${ }^{29} \mathrm{Si}$ NMR spectrum of silacyclopropene $\mathbf{3}$ displays a single resonance at $\delta-117.8 \mathrm{ppm}$. Contrary to $\mathbf{1}$ and $\mathbf{2}$, the $t \mathrm{Bu}$ protons attached to the nitrogen atoms of compound 3 in its ${ }^{1} \mathrm{H}$ NMR spectrum show a singlet at $\delta 1.09 \mathrm{ppm}$. The $t \mathrm{Bu}$ protons bound to the silicon atom show a resonance at $1.50 \mathrm{ppm}$. Compound 3 exhibits its molecular ion in the mass spectrum at $\mathrm{m} / \mathrm{z}$ 494.

The molecular structure of compound $\mathbf{3}$ is shown in Fig. 3. Compound 3 crystallizes in the triclinic space group $P \overline{1}$. The silicon atom is five coordinate and nearly in a square pyramidal geometry with $\tau=0.05$. The silicon coordination environment is derived from two nitrogen atoms and three carbon atoms. 


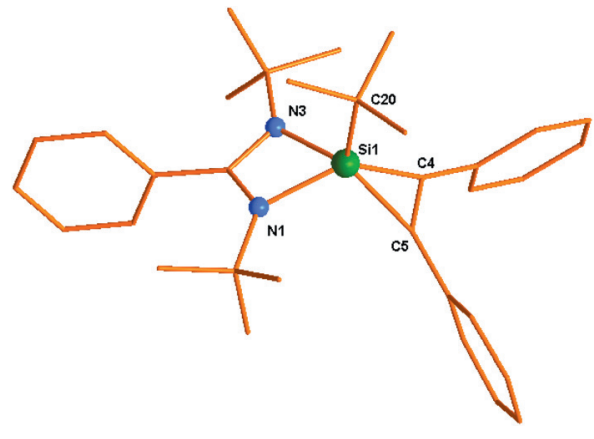

Fig. 3 Molecular structure of 3. Selected bond lengths $[\AA]$ and angles $\left[^{\circ}{ }^{\circ}:\right.$ Si1-N1 1.9062(11), Si1-N3 1.9199(12), Si1-C4 1.8282(14), Si1C5 1.8348(13), Si1-C20 1.9188(14), C4-C5 1.3574(19); N1-Si1-N3 68.29(5), N3-Si1-C5 134.54(6), N1-Si1-C20 106.03(6), N1-Si1-C4 137.34(6), N1-Si1-C5 108.21(5), C5-Si1-C4 43.50(6), C20-Si1-C5 116.16(6), Si1-C4-C5 68.51(8), C4-C5-Si1 67.99(8) ${ }^{\circ}$.

The bite angle (N1-Si1-N3) is $68.29(5)^{\circ}$. The angles of the newly formed $\mathrm{CSiC}$ three-membered ring are $\mathrm{C} 4-\mathrm{Si1}-\mathrm{C} 5\left(43.50(6)^{\circ}\right)$, Sil-C4-C5 $\left(68.51(8)^{\circ}\right)$ and C4-C5-Si1 $\left(67.99(8)^{\circ}\right)$, and the

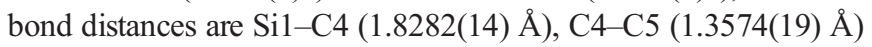
and Si1-C5 (1.8348(13) Å).

\section{Conclusions}

In summary, three-membered silicon heterocycles can be accessed by the reaction of base stabilized monoalkylsilylene $\mathrm{LSi} t \mathrm{Bu}$ with $\mathrm{PhN}=\mathrm{NPh}, \mathrm{PhN}=\mathrm{CHPh}$ and $\mathrm{PhC} \equiv \mathrm{CPh}$. Due to the presence of the bulky $t \mathrm{Bu}$ groups at the silicon(II) centers, the reactions of $\mathrm{LSi} t \mathrm{Bu}$ with $\mathrm{PhN}=\mathrm{NPh}$ and $\mathrm{PhC} \equiv \mathrm{CPh}$ show a different reactivity pattern compared to that of $\mathrm{LSiCl}$. Compound $\mathbf{1}$ is the first structurally isolated example of a three-membered siladiaziridine compound.

We thank the Deutsche Forschungsgemeinschaft for supporting this work. R. A. is thankful to the Alexander von Humboldt Stiftung for a research fellowship.

\section{Notes and references}

1 (a) Chemistry of Heterocyclic Compounds: Heterocyclic Compounds with Three- and Four-Membered Rings, ed. A. Weissberger, Wiley, New York, 2008, vol. 19; (b) M. Weidenbruch, Small Silicon Ring Compounds, in Organosilicon Chemistry I: From Molecules to Materials, ed. N. Auner and J. Weis, Wiley-VCH Verlag GmbH, Weinheim, 2008.

2 (a) G. Magyarfalvi and P. Pulay, Chem. Phys. Lett., 1995, 241, 393-398; (b) D. Cremer, J. Gauss and E. Cremer, J. Mol. Struct. (THEOCHEM), 1988, 169, 531-561.

3 R. S. Ghadwal, S. S. Sen, H. W. Roesky, M. Granitzka, D. Kratzert, S. Merkel and D. Stalke, Angew. Chem., Int. Ed., 2010, 49, 3952-3955, (Angew. Chem., 2010, 122, 4044-4047).

4 N. Jung and S. Bräse, Angew. Chem., Int. Ed., 2012, 51, 5538-5540, (Angew. Chem., 2012, 124, 5632-5634).

5 A. G. Brook, Acc. Chem. Res., 1974, 7, 77-84.

6 Z. Nevárez and K. A. Woerpel, J. Org. Chem., 2008, 73, 8113-8115.

7 N. A. Meanwell, Med. Chem., 2011, 54, 2529-2591.

8 T. Johansson, L. Weidolf, F. Popp, R. Tacke and U. Jurva, Drug Metab. Dispos., 2010, 38, 73-83.

9 (a) M. Haaf, T. A. Schmedake and R. West, Acc. Chem. Res., 2000, 33, 704-714; (b) B. Gehrhus and M. F. Lappert, J. Organomet. Chem., 2001, 617-618, 209-223; (c) S. S. Sen, S. Khan, P. P. Samuel and
H. W. Roesky, Chem. Sci., 2012, 3, 659-682; (d) M. Kira, Chem. Commun., 2010, 46, 2893-2903; (e) S. Yao, Y. Xiong and M. Driess, Organometallics, 2011, 30, 1748-1767; $(f)$ A. Sakakibara, Y. Kabe, T. Shimuzu and W. Ando, J. Chem. Soc., Chem. Commun., 1991, 43-44; (g) E. Gellermann, U. Klingebiel, M. Noltemeyer and S. Schmatz, J. Am. Chem. Soc., 2001, 123, 378-382; (h) J. Hluchy and U. Klingebiel, Angew. Chem., Int. Ed., 1982, 4, 301, (Angew. Chem., 1982, 94, 292); (i) K. Voijinović, L. J. McLachlan, S. L. Hinchley, D. W. H. Rankin and N. W. Mitzel, Chem.-Eur. J., 2004, 10, 3033-3042; (j) R. West, G. R. Gillette, H. B. Yokelson and A. J. Millevolte, Phosphorus, Sulfur Silicon Relat. Elem., 1989, 41, 3-14.

10 P. P. Gaspar and R. West, in The Chemistry of Organic Silicon Compounds, ed. Z. Rappoport and Y. Apeloig, 2nd edn, John Wiley and Sons, New York, 1999, vol. 2( (Part 3)), pp. 2463-2568.

11 M. Denk, R. Lennon, R. Hayashi, R. West, A. V. Belyakov, H. P. Verne, A. Haaland, M. Wagner and N. Metzler, J. Am. Chem. Soc., 1994, 116, 2691-2692.

12 C. Vollmer and C. Janiak, Coord. Chem. Rev., 2011, 255, 2039-2057.

13 (a) S. P. Nolan, in N-Heterocyclic Carbenes in Synthesis, ed. Wiley-VCH, Weinheim, Germany, 2006; (b) F. Glorius, in N-Heterocyclic Carbenes in Transition Metal Catalysis, ed. Springer-Verlag, Berlin, 2007; (c) A. Jana, R. Azhakar, G. Tavčar, H. W. Roesky, I. Objartel and D. Stalke, Eur. J. Inorg. Chem., 2011, 3686-3689.

14 D. P. Mills, L. Soutar, W. Lewis, A. J. Blake and S. T. Liddle, J. Am. Chem. Soc., 2010, 132, 14379-14381.

15 C.-W. So, H. W. Roesky, J. Magull and R. B. Ostwald, Angew. Chem., Int. Ed., 2006, 45, 3948-3950, (Angew. Chem., 2006, 118, 4052-4054).

16 S. S. Sen, H. W. Roesky, D. Stern, J. Henn and D. Stalke, J. Am. Chem. Soc., 2010, 132, 1123-1126.

17 (a) R. Azhakar, S. P. Sarish, H. W. Roesky, J. Hey and D. Stalke, Inorg. Chem., 2011, 50, 5039-5043; (b) G. Tavčar, S. S. Sen, R. Azhakar, A. Thorn and H. W. Roesky, Inorg. Chem., 2010, 49, 10199-10202; (c) R. S. Ghadwal, R. Azhakar, K. Pröpper, J. J. Holstein, B. Dittrich and H. W. Roesky, Inorg. Chem., 2011, 50, 8502-8508; (d) R. Azhakar, R. S. Ghadwal, H. W. Roesky, H. Wolf and D. Stalke, J. Am. Chem. Soc., 2012, 134, 2423-2428; (e) R. Azhakar, R. S. Ghadwal, H. W. Roesky, J. Hey and D. Stalke, Chem. Asian. J., 2012, 7, 528-533.

18 (a) R. Azhakar, S. P. Sarish, H. W. Roesky, J. Hey and D. Stalke, Organometallics, 2011, 30, 2897-2900; (b) P. W. Percival, J.-C. Brodovitch, M. Mozafari, A. Mitra, R. West, R. S. Ghadwal, R. Azhakar and H. W. Roesky, Chem.-Eur. J., 2011, 17, 11970-11973; (c) R. Azhakar, R. S. Ghadwal, H. W. Roesky, J. Hey and D. Stalke, Dalton Trans., 2012, 41, 1529-1533; (d) R. Azhakar, S. P. Sarish, G. Tavčar, H. W. Roesky, J. Hey, D. Stalke and D. Koley, Inorg. Chem., 2011, 50, 3028-3036; (e) R. Azhakar, R. S. Ghadwal, H. W. Roesky, J. Hey and D. Stalke, Organometallics, 2011, 30, 3853-3858; $(f)$ A. Jana, P. P. Samuel, G. Tavčar, H. W. Roesky and C. Schulzke, J. Am. Chem. Soc., 2010, 132, 10164-10170; ( $g$ ) R. S. Ghadwal, R. Azhakar, H. W. Roesky, K. Pröpper, B. Dittrich, S. Klein and G. Frenking, J. Am. Chem. Soc., 2011, 133, 17552-17555; (h) R. Azhakar, R. S. Ghadwal, H. W. Roesky, H. Wolf and D. Stalke, Organometallics, 2012, 31, 4588-4590.

19 (a) R. Azhakar, G. Tavčar, H. W. Roesky, J. Hey and D. Stalke, Eur. J. Inorg. Chem., 2011, 475-477; (b) A. Jana, R. Azhakar, S. P. Sarish, P. P. Samuel, H. W. Roesky, C. Schulzke and D. Koley, Eur. J. Inorg. Chem., 2011, 5006-5013.

20 R. Azhakar, R. S. Ghadwal, H. W. Roesky, H. Wolf and D. Stalke, Chem. Commun., 2012, 48, 4561-4563.

21 S. Khan, S. S. Sen, R. Michel, D. Kratzert, H. W. Roesky and D. Stalke, Organometallics, 2011, 30, 2643-2645.

22 (a) S. Yao, C. Van Wuellen, X.-Y. Sun and M. Driess, Angew. Chem., Int. Ed., 2008, 47, 3250-3253, (Angew. Chem., 2008, 120, 3294-3297); (b) R. S. Ghadwal, H. W. Roesky, S. Merkel, J. Henn and D. Stalke, Angew. Chem., Int. Ed., 2009, 48, 5683-5686, (Angew. Chem., 2009, 121, 5793-5796).

23 (a) A. W. Addison, T. N. Rao, J. Reedijk, J. van Rijn and G. C. Verschoor, J. Chem. Soc., Dalton Trans., 1984, 1349-1356; (b) V. Chandrasekhar, R. Azhakar, T. Senapati, P. Thilagar, S. Ghosh, S. Verma, R. Boomishankar, A. Steiner and P. Kögerler, Dalton Trans., 2008, 1150-1160.

24 (a) V. Chandrasekhar, R. Boomishankar, R. Azhakar, K. Gopal, A. Steiner and S. Zacchini, Eur. J. Inorg. Chem., 2005, 1880-1885; (b) S. P. Sarish, A. Jana, H. W. Roesky, P. P. Samuel, C. E. A. Andrade, B. Dittrich and C. Schulzke, Organometallics, 2011, 30, 912-916. 